\title{
EVALUATION OF COMPOSITION SUITABILITY OF THE MODEL FOR NEW SERVICE DEVELOPMENT
}

\author{
Ilona SKAČKAUSKIENĖ $@$, Povilas ŠVOGŽLYS $\mathbb{B}^{*}$ \\ Department of Management, Faculty of Business Management, \\ Vilnius Gediminas Technical University, Sauletekio al. 11, LT-10223, Vilnius, Lithuania
}

Received 28 May 2020; accepted 15 January 2021

\begin{abstract}
As more and more attention is paid to the formation of models of new service development, it is noticed that the compositions of a new model are usually based only on examples of previous models that were presented in the scientific literature. Although the practical application of the proposed models in any organizational condition is often verified by empirical studies, the revisions of the validity of model compositions are still quite fragmented. The lack of such research does not give the possibility for any further improvement of the model or elimination of the revealed shortcomings and it makes the proper preparation for testing the proposed model in a company complicated. In order to evaluate the suitability of the composition of the newly formed model of service development in the conditions of modern service companies, an empirical evaluation was performed by using the methods of abstraction, comparative analysis, synthesis, and expert survey. According to the results of the research, the suggestions for the improvement of the new service development model were made and guidelines for further research were formulated.
\end{abstract}

Keywords: expert evaluation, empirical evaluation, comparative analysis, model; new service development, service, suitability assessment, NSD, composition, model improvement.

JEL Classification: L80, M11.

Online supplementary material: Supporting information for this paper is available as online supplementary material at https://doi.org/10.3846/jbem.2021.14589

\section{Introduction}

The interest in models for new services development (NSD) (Burger et al., 2010; Lin \& Hsieh, 2011; Edvardsson et al., 2013; Santos \& Spring, 2013; Geissdoerfer et al., 2018; Santana et al., 2018; Bauer \& Borodako, 2019) was growing over the last decade, as a result, it is noticeable that the formation process of such models is usually based on a similar analogy. The formation of the model of NSD begins with the analysis described in the scientific literature when the choices of stages and activities assigned to them are theoretically proved. The process of

*Corresponding author. E-mail: povilas.svogzlys@vilniustech.lt

Copyright $\odot 2021$ The Author(s). Published by Vilnius Gediminas Technical University

This is an Open Access article distributed under the terms of the Creative Commons Attribution License (http://creativecommons. org/licenses/by/4.0/), which permits unrestricted use, distribution, and reproduction in any medium, provided the original author and source are credited. 
formation ends up with empirical testing in real service companies. There is a lack of empirical research on whether the stages proposed in the model and the activities assigned to them were selected properly. The evaluation of the composition suitability of the NSD model would provide a lot of useful information for further improvement. According to such information, it would be possible to eliminate the shortcomings of the model and change the assigned activities for each stage. This research would also help to evaluate the readiness to test the proposed model in a company and would provide some guidelines for further research. In order to evaluate the suitability of the composition of the proposed NSD model in a real service company while taking the above-mentioned aspects into account, an empirical study was conducted by using the method of an expert survey.

The aim of the research: to evaluate the suitability of the composition of the proposed NSD model and to provide recommendations for its further development.

In order to reach the aim of this research the following goals were set: 1) to conduct a survey of experts from Lithuanian and Danish companies of the service sector; 2) to improve the composition of the NSD model according to the results of the research; 3) to provide recommendations for the application of the NSD model in companies.

The research was conducted by using the methods of abstraction, comparative analysis, synthesis, and expert survey.

\section{An overview of the latest NSD models}

The homogeneity of the services offered by the market, the constantly changing behaviour of consumers, and the increased demand for technological innovations in the field of services are encouraging companies to seek for new solutions to develop, implement and launch new services. In this context, the models of NSD get a very significant role as they enable companies to increase the speed of NSD, raise the quality of providing services, describe the targeted consumer, make the process of organizing the whole process smooth, as well as, to involve employees and consumers in every stage. Many scholars try to form a model of NSD by following new trends of the service sector, consumer needs or evaluating the effectiveness and adaptability of models developed in the past (see Table 1).

Table 1. Comparison of the latest NSD models (source: compiled by the authors)

\begin{tabular}{|l|l|c|c|c|c|c|}
\hline \multicolumn{1}{|c|}{ Author, year } & \multicolumn{1}{|c|}{ NSD model name } & $\begin{array}{c}\text { Sta- } \\
\text { ges }\end{array}$ & $\begin{array}{c}\text { Acti- } \\
\text { vities }\end{array}$ & $\begin{array}{c}\text { Model } \\
\text { type } \\
\text { (cyclic / } \\
\text { linear / } \\
\text { complex })\end{array}$ & $\begin{array}{c}\text { External } \\
\text { environ- } \\
\text { ments } \\
\text { in NSD } \\
\text { model }\end{array}$ & $\begin{array}{c}\text { Empirical } \\
\text { study of } \\
\text { NSD model } \\
\text { composition } \\
\text { improvement }\end{array}$ \\
\hline \multicolumn{1}{|c|}{1} & 2 & 3 & 4 & 5 & 6 & 7 \\
\hline $\begin{array}{l}\text { Burger et al. } \\
(2010)\end{array}$ & The proposed NSD model & 6 & 18 & Linear & - & - \\
\hline $\begin{array}{l}\text { Lin and Hsieh } \\
(2011)\end{array}$ & $\begin{array}{l}\text { Stage-Activity Framework } \\
\text { of NSD }\end{array}$ & 5 & 16 & Linear & - & - \\
\hline Gaus et al. (2013) & $\begin{array}{l}\text { Modified NSD model in } \\
\text { accordance with Gustafsson } \\
\text { and Johanson }\end{array}$ & 7 & - & Complex & $\begin{array}{c}\text { Con- } \\
\text { sumers } \\
\text { and com- } \\
\text { petitors }\end{array}$ & - \\
\hline
\end{tabular}


End of Table 1

\begin{tabular}{|c|c|c|c|c|c|c|}
\hline 1 & 2 & 3 & 4 & 5 & 6 & 7 \\
\hline \begin{tabular}{|l} 
Santos and \\
Spring (2013)
\end{tabular} & NSD process scheme & 3 & - & Complex & - & $\checkmark$ \\
\hline \begin{tabular}{|l} 
Edvardsson et al. \\
$(2013)$
\end{tabular} & A conceptual model for NSD & 5 & - & Complex & $\begin{array}{l}\text { Con- } \\
\text { sumers }\end{array}$ & - \\
\hline $\begin{array}{l}\text { Yu and Sangiorgi } \\
(2014)\end{array}$ & NSD research framework & 4 & 3 & Complex & $\begin{array}{l}\text { Con- } \\
\text { sumers }\end{array}$ & - \\
\hline Jin et al. (2014) & NSD maturity model & 4 & - & Cyclic & & - \\
\hline $\begin{array}{l}\text { Drejeris and } \\
\text { Vesterte (2015) }\end{array}$ & $\begin{array}{l}\text { Model of the process of de- } \\
\text { veloping new public services }\end{array}$ & 4 & 16 & Complex & - & - \\
\hline Drejeris (2015) & $\begin{array}{l}\text { Model for development } \\
\text { and implementation of new } \\
\text { services }\end{array}$ & 3 & 5 & Complex & - & - \\
\hline Hsu (2017) & Service blueprint in NSD & 6 & 15 & Complex & $\begin{array}{l}\text { Con- } \\
\text { sumers }\end{array}$ & - \\
\hline $\begin{array}{l}\text { Santana et al. } \\
(2018)\end{array}$ & $\begin{array}{l}\text { The Universal Design } \\
\text { Service model }\end{array}$ & 7 & 17 & Complex & $\begin{array}{l}\text { Con- } \\
\text { sumers }\end{array}$ & - \\
\hline $\begin{array}{l}\text { Bauer and } \\
\text { Borodako (2019) }\end{array}$ & $\begin{array}{l}\text { Conceptual Framework of a } \\
\text { trade show innovation's NSD } \\
\text { process leading to project } \\
\text { authorization }\end{array}$ & 5 & - & Linear & - & $\checkmark$ \\
\hline
\end{tabular}

The results of the comparative analysis of the NSD models revealed the following aspects that are important for the formation of a model and its further testing. While developing new models, many researchers (Lin \& Hsieh, 2011; Santos \& Spring, 2013; Edvardsson et al., 2013; Yu \& Sangiorgi, 2014; Jin et al., 2014; Drejeris, 2015; Drejeris \& Vesterte், 2015; Bauer \& Borodako, 2019) tend to assign from 3 to 5 stages to every new model. The latest trend is to decrease the number of stages while many previous models (Scheuing \& Johnson, 1989; Alam \& Perry, 2002) presented in the scientific literature included 10 up to 15 stages per model. This tendency suggests the idea that a smaller number of stages might be enough in the NSD model and the suitability of a new model can be maintained by the inclusion of some additional actions (Švogžlys, 2020). Kitsios and Kamariotou (2019) explain that the main reason why the number of stages was decreased might be the seek of researchers to make the overall process more fluent. It has also been observed that modern models of NSD pay less attention to the formation of external environments. In this way, several actions can be combined into one group (Skačkauskienè et al., 2019). Most of the stages of other models and the activities assigned to those stages are mostly focused only on employee-related factors. The features related to consumers or competitor environments were found in 5 of the 12 models that have been analyzed. It was also noticed that all these models belong to the category of complex models. This insight encourages further analysis of the process of developing new services not only at the level of stage but also at the level of environments (company, consumers, and competitors) (see Table 2). Finally, the hints about the evaluation of the suitability of the composition of the NSD model were found in the works of only two authors. The above-mentioned insights lead to the conclusion that the results of this research 
could be useful in practice, as well as, could provide some benefits to the scientific area of business management about the possibilities of improving the composition of a NSD model and the readiness to test the proposed model in a company.

Table 2. Main activities included in preparation, analysis, formation and realization stages of NSD process (source: Švogžlys, 2020)

\begin{tabular}{|c|c|c|}
\hline Environment & $\begin{array}{l}\text { Main activities } \\
\text { assigned to stage }\end{array}$ & Author, year \\
\hline \multicolumn{3}{|r|}{ 1. Preparation stage } \\
\hline Company & $\begin{array}{l}\text { Generation of new } \\
\text { ideas }\end{array}$ & $\begin{array}{l}\text { Torney et al. (2009), Burger et al. (2010), Gaus et al. } \\
\text { (2013), Rapaccini et al. (2013), Drejeris and Vesterte } \\
\text { (2015), Yu and Sangiorgi (2018) }\end{array}$ \\
\hline Competitors & $\begin{array}{l}\text { Evaluation of the } \\
\text { exclusivity of ideas }\end{array}$ & $\begin{array}{l}\text { Stevens and Dimitriadis (2005), Reinoso et al. (2009), } \\
\text { Burger et al. (2010), Gaus et al. (2013), Zeithaml et al. } \\
\text { (2017) }\end{array}$ \\
\hline \multirow[t]{2}{*}{ Consumers } & $\begin{array}{l}\text { Generating ideas } \\
\text { with consumer } \\
\text { involvement }\end{array}$ & $\begin{array}{l}\text { Shekar (2007), Reinoso et al. (2009), Jin et al. (2014), Hsu } \\
\text { (2017), Zeithaml et al. (2017) }\end{array}$ \\
\hline & $\begin{array}{l}\text { Evaluation of the } \\
\text { suitability of ideas }\end{array}$ & $\begin{array}{l}\text { Reinoso et al. (2009), Gaus et al. (2013), Jin et al. (2014), } \\
\text { Zeithaml et al. (2017) }\end{array}$ \\
\hline \multicolumn{3}{|r|}{ 2. Analysis stage } \\
\hline \multirow{2}{*}{ Company } & $\begin{array}{l}\text { Assessment } \\
\text { of employee } \\
\text { competence }\end{array}$ & $\begin{array}{l}\text { Froehle and Roth (2007), Santos and Spring (2013), } \\
\text { Zeithaml et al. (2017) }\end{array}$ \\
\hline & $\begin{array}{l}\text { Cost-benefit } \\
\text { analysis }\end{array}$ & $\begin{array}{l}\text { Reinoso et al. (2009), Lin and Hsieh (2011), Santos and } \\
\text { Spring (2013), Zeithaml et al. (2017), Santana et al. (2018) }\end{array}$ \\
\hline Competitors & Market Analysis & $\begin{array}{l}\text { Stevens and Dimitriadis (2005), Reinoso et al. (2009), Lin } \\
\text { and Hsieh (2011), Gaus et al. (2013), Santana et al. (2018) }\end{array}$ \\
\hline Consumers & $\begin{array}{l}\text { Identifying } \\
\text { consumer needs }\end{array}$ & $\begin{array}{l}\text { Stevens and Dimitriadis (2005), Gaus et al. (2013), Yu and } \\
\text { Sangiorgi (2014), Jin et al. (2014), Santana et al. (2018), } \\
\text { Hsu (2017) }\end{array}$ \\
\hline \multicolumn{3}{|r|}{ 3. Formation stage } \\
\hline \multirow{3}{*}{ Company } & $\begin{array}{l}\text { Formation of a } \\
\text { conceptual service }\end{array}$ & $\begin{array}{l}\text { Lin and Hsieh (2011), Edvardsson et al. (2013), Gaus } \\
\text { et al. (2013), Drejeris and Vesterte (2015), Zeithaml et al. } \\
\text { (2017), Santana et al. (2018) }\end{array}$ \\
\hline & \begin{tabular}{|l|} 
Employee \\
involvement
\end{tabular} & $\begin{array}{l}\text { Shekar (2007), Froehle and Roth (2007), Zeithaml et al. } \\
\text { (2017), Hsu (2017) }\end{array}$ \\
\hline & Staff training & $\begin{array}{l}\text { Stevens and Dimitriadis (2005), Froehle and Roth (2007), } \\
\text { Reinoso et al. (2009), Riedl et al. (2011), Zeithaml et al. } \\
\text { (2017), Hsu (2017), Santana et al. (2018) }\end{array}$ \\
\hline Competitors & $\begin{array}{l}\text { Additional business } \\
\text { analysis }\end{array}$ & Lin and Hsieh (2011), Gaus et al. (2013) \\
\hline \multirow[t]{2}{*}{ Consumers } & \begin{tabular}{|l|} 
Consumer \\
involvement
\end{tabular} & $\begin{array}{l}\text { Gaus et al. (2013), Yu and Sangiorgi (2014), Zeithaml et al. } \\
\text { (2017), Hsu (2017) }\end{array}$ \\
\hline & $\begin{array}{l}\text { Evaluation } \\
\text { of Consumer } \\
\text { Proposals }\end{array}$ & $\begin{array}{l}\text { Jin et al. (2014), Yu and Sangiorgi (2014), Zeithaml et al. } \\
\text { (2017), Hsu (2017) }\end{array}$ \\
\hline
\end{tabular}


End of Table 2

\begin{tabular}{|c|c|c|}
\hline Environment & $\begin{array}{l}\text { Main activities } \\
\text { assigned to stage }\end{array}$ & Author, year \\
\hline \multicolumn{3}{|r|}{ 4. Realization stage } \\
\hline \multirow{2}{*}{ Company } & Launch & $\begin{array}{l}\text { Reinoso et al. (2009), Gaus et al. (2013), Rapaccini et al. } \\
\text { (2013), Yu and Sangiorgi (2014), Santana et al. (2018) }\end{array}$ \\
\hline & $\begin{array}{l}\text { Marketing related } \\
\text { actions }\end{array}$ & $\begin{array}{l}\text { Lin and Hsieh (2011), Reinoso et al. (2009), Rapaccini } \\
\text { et al. (2013), Hsu (2017). }\end{array}$ \\
\hline Competitors & $\begin{array}{l}\text { Evaluate the } \\
\text { reaction of } \\
\text { competitors }\end{array}$ & Shekar (2007), Gaus et al. (2013), Zeithaml et al. (2017) \\
\hline \multirow[b]{2}{*}{ Consumers } & $\begin{array}{l}\text { Test of a new } \\
\text { service }\end{array}$ & $\begin{array}{l}\text { Gaus et al. (2013), Santana et al. (2018), Hsu (2017), } \\
\text { Zeithaml et al. (2017) }\end{array}$ \\
\hline & Post-launch review & $\begin{array}{l}\text { Torney et al. (2009), Lin and Hsieh (2011), Gaus et al. } \\
\text { (2013), Edvardsson et al. (2013), Yu and Sangiorgi (2018), } \\
\text { Santana et al. (2018) }\end{array}$ \\
\hline
\end{tabular}

After analyzing what stages of the process of NSD (preparation, analysis, formation, realization) and environments (company, consumers, competitors) include some additional actions, the 19 most frequently mentioned actions were identified. According to the results of the analysis, a schematic diagram of the NSD model has been prepared where the general layout of the environments, stages, and the actions assigned to them were distinguished (see Figure 1).

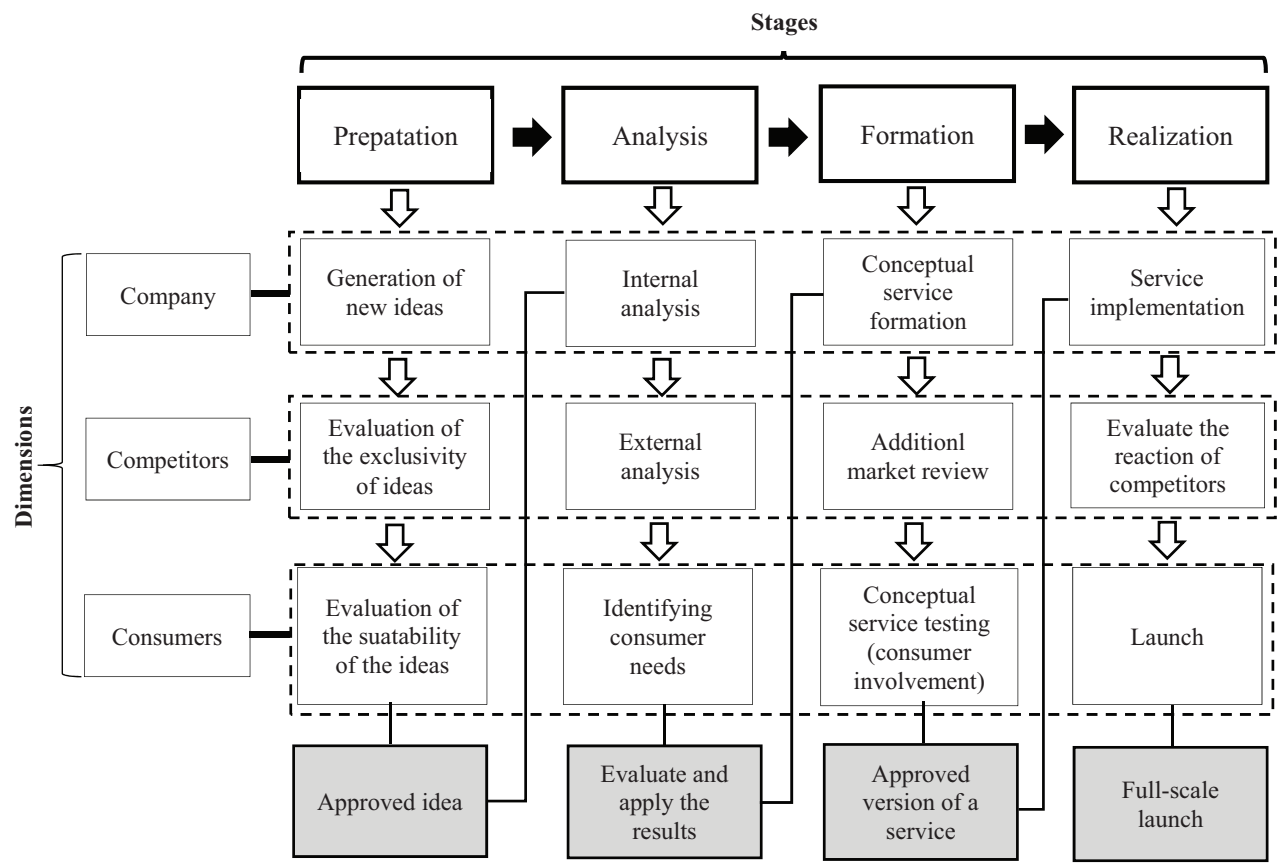

Figure 1. Principal scheme of the NSD model (source: Švogžlys, 2020) 
Following the structure of this schematic diagram, the model of new service development is formed, its unique features are presented and the implementation algorithm is also presented.

\section{Proposed model for NSD}

A complex model of NSD has been proposed (Skačkauskienè et al., 2019) for companies that (1) develop a brand new service; (2) want to change the direction of activities; (3) seek to expand their range of services; or (4) use the already existing products to develop a new service. The proposed model for NSD could be considered as a tool that will allow a rational evaluation of the opportunities to develop a new service and all possible risks, as well as, to ensure a constructive organization of the workload for all subjects involved in this process. This model will help companies properly evaluate the uniqueness of the selected ideas, identify risks related to the internal and external environments, assess the need to involve consumers, find the best solution to schedule the timetables and divide the workload and prepare themselves for the launching process.

The proposed model for the development of a new service is outstanding because of its structure when every activity of the model can be analysed at different stages of the development process, as well as, in different environments where are they placed. The model consists of 4 stages (preparation, analysis, formation, and realization) and 3 environments (company, competitors and consumers). Each of these environments can cover all stages and each of the above-mentioned stages covers all the environments. This composition of the model allows a service provider to manage the service development process rationally, evaluate the internal environments of the company or external factors affecting the process.

During the stages of preparation, analysis, formation, and realization, the process of NSD begins with questions. The answers are based on the results that the business subject must achieve at the end of each stage in order to move to the next step. The preparation stage must be completed when the final idea of a new service has been approved. The analysis stage is closed after the evaluation of all results and their application to the conceptual service. The formation stage is completed with an approved version of the conceptual service. Finally, the realization stage ends up with a full-scale launch of a new service. Once the realization stage is finished, the development of new service is completed and it is ready to be introduced to the consumers. If the need for a new service emerges, the whole process can be repeated again from the beginning.

When the internal aspects of the company highlight the key aspects of NSD, then the overall staff readiness and estimated costs are evaluated. During the formation stage of a conceptual service, the simulation is performed among the employees of the company while their suggestions and recommendations for improvement of a new service are evaluated. After this simulation, the processes of installation and realization is begun.

In order to evaluate external factors that might have an impact on the development of a new service, the environments of competitors and consumers are distinguished in the developed model. The overall uniqueness of the ideas, all potential threats, the segment to which the service is going to oriented, as well as the possible reaction of the competitors to a newly 
developed service are evaluated in the environment of competitors. In the environment of consumers, the relevance of the service according to the needs of the targeted audience, their specific groups of consumers and their inclusion capabilities are evaluated.

The completed model of NSD has features that make it distinctive in the overall context of all models for NSD. First of all, the structure of this model is detailed, as a result, each of the different environments (company, competitors and consumers) can be analysed at different stages of the development of the model. This enables the service provider to identify the activities taken at each stage, plan the necessary resources and responsibilities. Secondly, in order to identify an impact of the external factors on the process of NSD, the environments of competitors and consumers are distinguished too. Competitors are evaluated by analysing the threats, market supply and their response to a new service that is ready to be provided. Meanwhile, consumers are analysed by assessing their needs and opportunities for involvement. Finally, a monitoring activity is included in the stage of realization and it includes a short-term post-launch review of a new service. This activity allows the business subject to determine what actions and final improvements are necessary to be made before the fullscale launch of a service. The algorithm of implementation is proposed for the application of the model of NSD (see Figure 2).

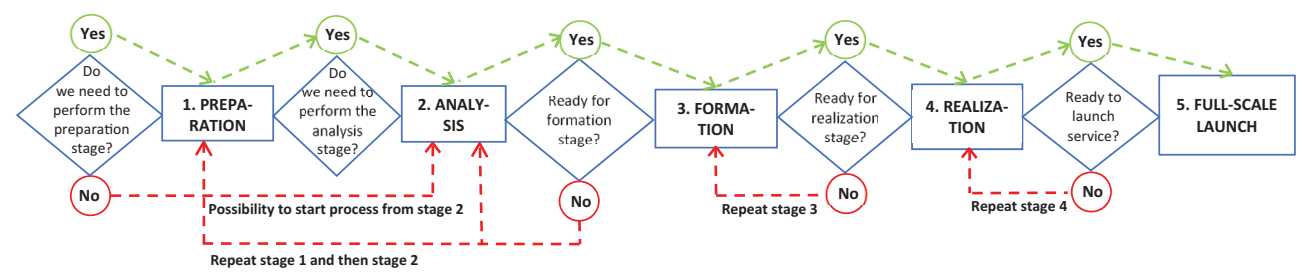

Figure 2. Algorithm for the implementation of the 3C service development model (source: Skačkauskienè et al., 2019)

According to the structure of the model for NSD, the analogical four stages are distinguished in the algorithm of implementation and the process might be ended by introducing this new service to the market. The process of service development can be done sequentially or some stages might be eliminated if they are not necessary due to the previous experience of the business subject.

\section{Evaluation methodology of composition suitability of the model for NSD}

The evaluation of the suitability of a model composition is necessary to get insights about its limitations, defects, and further improvements. It is noticeable that the authors of some researchers (Shekar, 2007; Froehle \& Roth, 2007; Lin \& Hsieh, 2011; Santos \& Spring, 2013; Drejeris, 2015; Hsu, 2017) use the method of peer review when designing their own models for NSD. The peer review can be described as a survey of the target groups of respondents who have knowledge and experience in a specific area. According to Yousuf (2007), the method of peer review ensures the full confidentiality to all respondents and is very useful when a researcher has no access to historical data. For these reasons, the suitability of the model, and the basis of the selected activities have been evaluated by using the expert survey. 
The selection of experts has been designed according to the companies in the Lithuanian and Danish service sector that are developing any new service at the moment or have been developed a new service recently. Lund et al. (2019) note that the sector of information and communications technology (ICT) grew the fastest among other areas of the services sector from 2007 to 2017 (see Figure 3). Meanwhile, according to the data of Eurostat (2017), the value created by the sector of information and communications technology through services was more than $3 \%$ and the value received through production was only $0.3 \%$ from 2012 to 2017. It is also noted that in 2017, the activities related to coding and development of information technology generated the most significant value of the sector of information and communications technology (overall 49\%). The proposed model is not only focused on the development of services of information technology. However, the experts were selected from IT development companies. Following the tendencies of growth of the ICT sector, the rapidly growing demand for specialists of this sector, and the recently adjusted innovations (Corrocher \& Ozman, 2019; Mas et al., 2019; Cioacă et al., 2020).

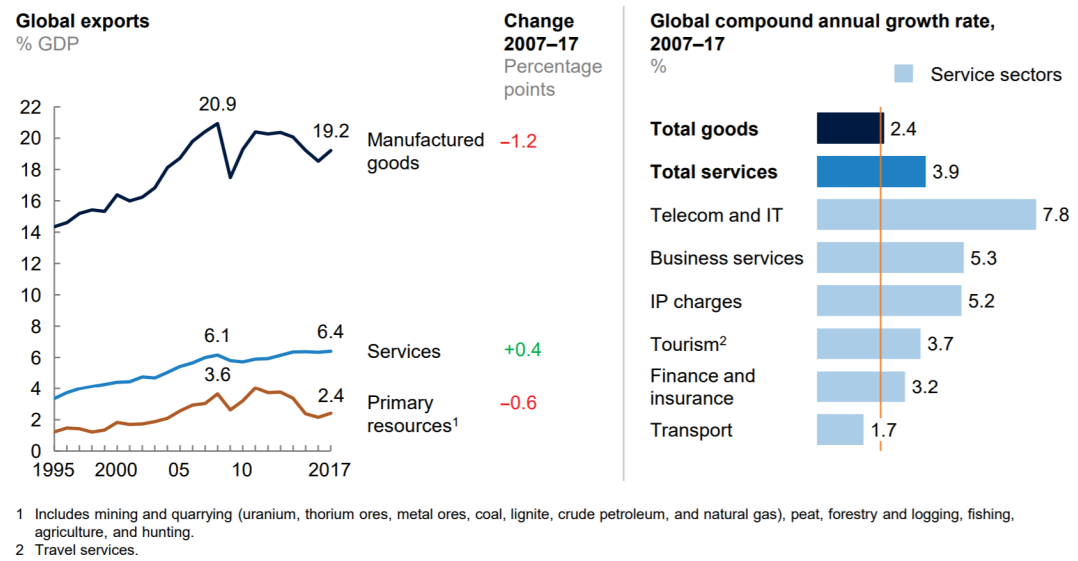

Figure 3. Global dynamics of the service sectors over the period 2007-2017 (source: Lund et al., 2019)

The experts were selected based on 5 criteria related to their overall competence: (1) ongoing or not later than one year ago finished projects of NSD; (2) overall work experience in companies of the service sector (not less than 11 years); (3) overall experience in NSD (not less than 6 years); (4) education (higher education); (5) current job position (managing position). According to Pridotkienè and Pridotkas (2012), the most accurate results can be obtained when experts have no chances to impact the opinions of each other, as a result, all respondents were selected from different companies.

The final number of experts was based on the opinion of Libby and Blashfield (1978) that the reliability of decisions and the number of experts are related to the rapidly fading non-linear relationship. The implication is that the estimation made by a small group (e.g. 7-9 experts) can be as reliable as the estimation made the larger group because the standard deviation is practically not changing with the eighth expert.

Accordingly, it can be assumed that the answers of 7 to 9 experts are enough to conduct the survey. 55 experts were offered to participate in this survey and 18 of them accepted their 
participation. Considering the criteria of the survey, 9 Lithuanian experts were finally selected (additional information about Lithuanian experts can be found in the supplemental file).

In the next stage of the research, the experts who work in the Danish companies of the service sector were interviewed in order to improve the evaluation of the suitability of the composition of the NSD model with data from a more technologically advanced country of the EU. It was decided to interview the experts from this country for the following reasons:

According to the report of Bank of Lithuania (2020) for the fourth quarter of 2019 "Exports and Imports of Services By Type of Service and Country", Denmark is among the ten countries to which Lithuania exports the major part of its services related to information technology. This fact suggests that both countries are cooperating closely and sharing their best practices regarding this business area.

According to the data of the European Commission (2019), the Danish sector of information and communication technology outperformed Lithuania in two positions: in 2016, the added value created by this sector in Denmark and the number of specialists working in it exceeded the same indications of Lithuania more than three times. Taking the larger scale of the Danish ICT sector into account, it can be assumed that the required number of experts can be found there to complete the research and it would be possible to select companies from a wider range (without choosing the branches of the same brands).

According to the report of the Eurostat (2019) about the EU high-tech statistics, it was observed that the average annual employment growth rate in activities that require a lot of specific knowledge was the same in Denmark and Lithuania from 2008 to 2017. Even though Denmark is a leader in many positions in the ICT sector, it might be assumed that both countries pay a lot of attention to high technology, its development, and the need to involve more professionals in it.

81 experts from different Danish IT companies were invited to take a part in the expert survey. 19 experts accepted the invitation, but only 9 were selected according to the previously set criteria (additional information about Danish experts can be found in the supplemental file). The questionnaires were sent to selected experts via e-mail. Based on the established model structure, all experts were presented with four blocks of questions (preparation, analysis, formation, and realization) where they had to give a score from 1 to 8 to the ( $1-$ very important, 8 - totally irrelevant). To obtain additional information about the improvement possibilities of the model, all experts were also asked to answer 4 open questions.

\section{Survey results of experts in Lithuanian and Danish companies that provide services for business}

The results of the expert survey were processed in three steps. During the initial step, the Kendall Concordance Coefficient (Kendall, 1970) was calculated to evaluate the compatibility of all opinions expressed by the experts. During the second step, all items were ranked by giving each of them a specific rank. As a result, it was possible to determine which activities of the model for NSD were considered as the most important or least important during every stage of the proposed model (see Table 3). Finally, according to the results of the survey, the recommendations for model improvements were provided. 


\begin{tabular}{|c|c|c|c|c|c|c|c|c|c|}
\hline \multirow{3}{*}{ 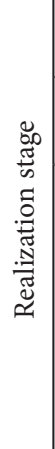 } & 范 光 & - & $N$ & 6 & $\wedge$ & $\infty$ & $m$ & in & H \\
\hline & 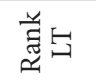 & 0 & N & in & $\infty$ & $n$ & - & $n$ & $H$ \\
\hline & 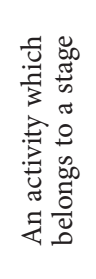 & 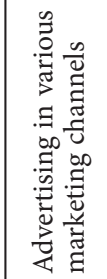 & 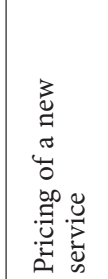 & 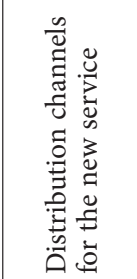 & 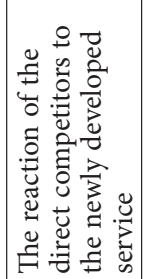 & 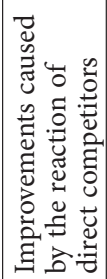 & 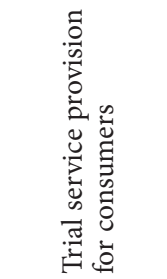 & 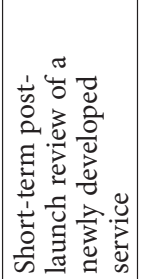 & 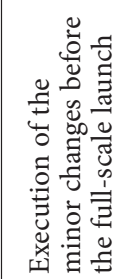 \\
\hline \multirow[b]{3}{*}{ 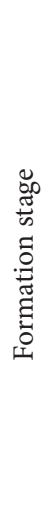 } & 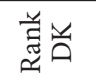 & $\sim$ & $n$ & $r$ & $\wedge$ & $\infty$ & - & in & 6 \\
\hline & 烒 & $N$ & $m$ & 6 & $n$ & $\infty$ & - & $r$ & in \\
\hline & 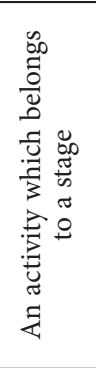 & 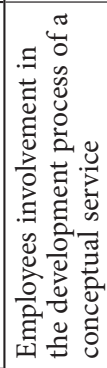 & 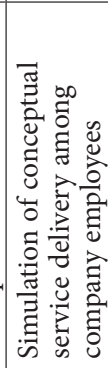 & 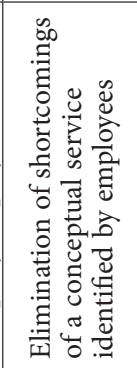 & 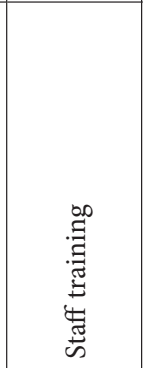 & 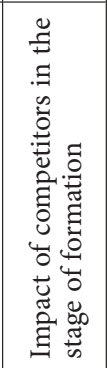 & 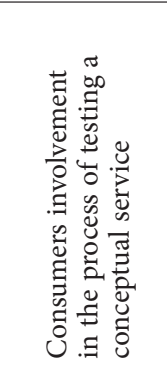 & 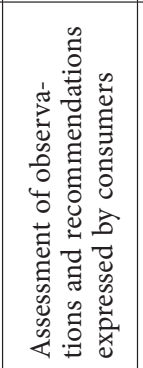 & 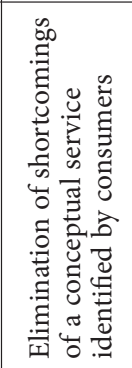 \\
\hline \multirow[b]{3}{*}{ 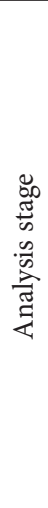 } & 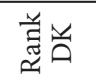 & $\wedge$ & $m$ & N & in & $\infty$ & - & $r$ & 0 \\
\hline & 莽 & 0 & 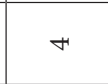 & $\sim$ & $n$ & $\infty$ & - & in & $m$ \\
\hline & 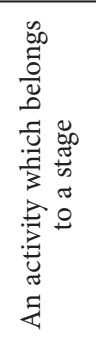 & 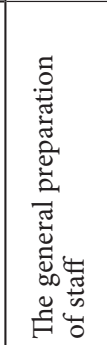 & 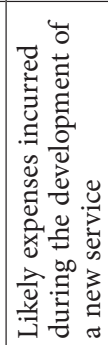 & 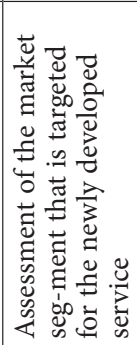 & 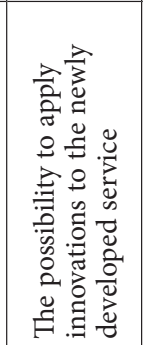 & 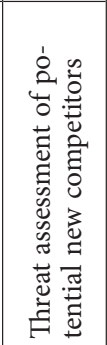 & 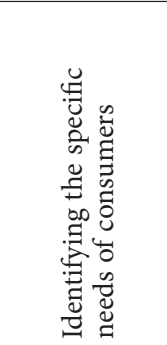 & 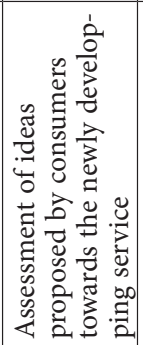 & 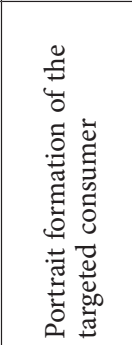 \\
\hline \multirow{3}{*}{ 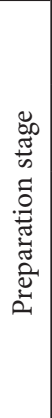 } & 華 光 & $\neg$ & $r$ & 6 & in & $\wedge$ & $N$ & $m$ & $\infty$ \\
\hline & 華兒 & - & $\sim$ & $\wedge$ & in & 6 & $\psi$ & $m$ & $\infty$ \\
\hline & 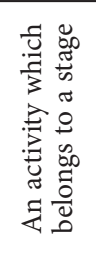 & 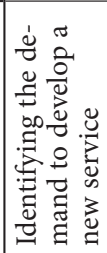 & 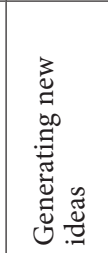 & 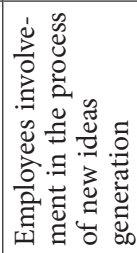 & 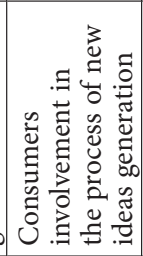 & 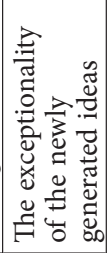 & 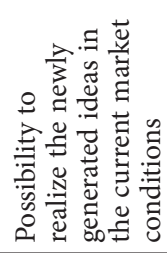 & 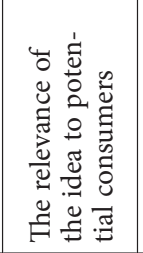 & 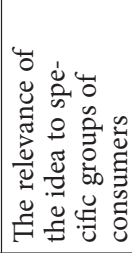 \\
\hline
\end{tabular}


When the scores assigned to the actions of the stages were summed up and the ranks were assigned according to the scores, the following similarities of the opinions of Lithuanian and Danish experts were observed:

1. While most of the experts have highlighted the role of the consumer in the process of NSD (the importance to identify the specific needs of consumers is highlighted during the stage of analysis, consumer involvement in conceptual service testing is considered as an important activity in the stage of formation, the trial service provision for consumers is considered as the key activity of the realization stage) experts have not highlighted the possibility to use recommendations or suggestions provided by consumers.

2. During the stage of realization, the following activities were evaluated as moderately important: "Short-term post-launch review of a newly developed service" (an average score in Lithuania was 3 and in Denmark 5) and "Execution of the minor changes before the full-scale launch" (an average score in both countries was 4). These insights reveal that additional verification activities before launching a newly developed service are relevant to business subjects and these activities could provide some additional information about the necessary improvements.

3. Both Danish and Lithuanian experts did not give much importance to the actions that belong to the environment of competitors in the stages of analysis, formation, and realization. In this case, these actions were given 7 points (irrelevant) or 8 points (completely irrelevant). Therefore, it might be assumed, that the development of a new service is based on the user experience, as a result, the environment of competitors is less important than the environments of organization and consumers. The experts hold a similar attitude while they are evaluating the element of employees involved in the process of new ideas generation as it was defined as less important. These results can be based on the fact that most of the new ideas are dictated by the market and consumer needs.

The Kendall concordance coefficient was calculated after estimating the distribution of opinions of experts working in Lithuanian and Danish business enterprises. First, the compatibility of opinions expressed by the Lithuanian experts was calculated (see Table 4).

Table 4. Results of compatibility of Lithuanian experts' opinions (source: compiled by the authors)

\begin{tabular}{|l|c|c|c|l|}
\hline \multicolumn{5}{|c|}{ Compatibility of experts opinions in the first test } \\
\hline Stage of the NSD model & $S$ & $S_{\max }$ & $W$ & Compatibility of opinions \\
\hline Preparation stage & 2052 & 3402 & 0.6032 & Compatible \\
\hline Analysis stage & 2124 & 3402 & 0.6243 & Compatible \\
\hline Formation stage & 2048 & 3402 & 0.6020 & Compatible \\
\hline Realization stage & 2078 & 3402 & 0.6108 & Compatible \\
\hline \multicolumn{4}{|c|}{ Compatibility of experts opinions in the second test } \\
\hline Stage of the NSD model & $\chi^{2}$ & $\chi_{k r}^{2}$ & Compatibility of opinions \\
\hline Preparation stage & 38.00 & 14.07 & Compatible \\
\hline Analysis stage & 39.33 & 14.07 & Compatible \\
\hline Formation stage & 37.93 & 14.07 & Compatible \\
\hline Realization stage & 38.48 & 14.07 & Compatible \\
\hline
\end{tabular}


The compatibility of opinions expressed by the experts is considered sufficient when the condition $W>0.6$ is met (Šateikienè et al., 2015; Akhmetshin et al., 2019). According to Motiene et al. (2017), only if this condition is met, the results of the research can be used for making further recommendations. After calculating the Kendall Concordance Coefficient, it was found that the concordance coefficient $W$ which represents the opinions expressed by the Lithuanian experts about the importance of the activities presented during the different stages of the model for NSD is slightly higher than 0.6 , as a result, the compatibility is considered sufficient.

Kendall (1970) has proved that, if the number of objects (in this case the number of activities in stage) is $m>7$, the significance of the concordance coefficient and the compatibility of the opinions of experts might be checked by using criterion $\chi^{2}$ :

$$
\chi^{2}=W r(m-1)=\frac{12 S}{r m(m+1)} .
$$

In this case, $r$ is the number of experts, $m$ is the number of criteria for evaluation, $S$ is the sum of squares of deviations from their overall mean of the sum of the indices, $W$ is the value of the concordance coefficient.

According to the chosen significance value $\alpha$ (in practice, the value of $\alpha$ is usually 0.05 or 0.01 ) from the $\chi^{2}$ distribution table with $v=m-1$ degree of error the critical value $\chi_{k r}{ }^{2}$ is found. When the value of $\chi^{2}$ that was calculated by following the formula (1) is greater than the critical value of $\chi_{k r}^{2}$, it might be determined that the assessments of experts are compatible (Podvezko, 2008). When calculating the value of $\chi^{2}$ when the selected significance value is $\alpha=0.05$ and the degree of freedom is $v=7$, it was found that the opinions of expert were also compatible, because $\chi^{2}>\chi_{k r}^{2}$.

Following a similar method, the compatibility of the opinions expressed by the Danish experts about the appropriateness of the design of the NSD model was also calculated (see Table 5).

Table 5. Results of compatibility of Danish experts' opinions (source: compiled by the authors)

\begin{tabular}{|c|c|c|c|c|}
\hline \multicolumn{5}{|c|}{ Compatibility of experts opinions in the first test } \\
\hline Stage of the NSD model & $S$ & $S_{\max }$ & $W$ & Compatibility of opinions \\
\hline Preparation stage & 1774 & 3402 & 0.5215 & Not compatible \\
\hline Analysis stage & 1618 & 3402 & 0.4756 & Not compatible \\
\hline Formation stage & 1902 & 3402 & 0.5591 & Not compatible \\
\hline Realization stage & 2058 & 3402 & 0.6049 & Compatible \\
\hline \multicolumn{5}{|c|}{ Compatibility of experts opinions in the second test } \\
\hline Stage of the NSD model & $\chi^{2}$ & \multicolumn{2}{|c|}{$\chi_{k r}^{2}$} & Compatibility of opinions \\
\hline Preparation stage & 32.85 & \multicolumn{2}{|c|}{14.07} & Compatible \\
\hline Analysis stage & 29.96 & \multicolumn{2}{|c|}{14.07} & Compatible \\
\hline Formation stage & 35.22 & \multicolumn{2}{|c|}{14.07} & Compatible \\
\hline Realization stage & 38.11 & \multicolumn{2}{|c|}{14.07} & Compatible \\
\hline
\end{tabular}


After calculating the compatibility of opinions expressed by the Danish experts while following the first method, it was found that the stages of preparation, analysis, and formation of the NSD model have $W<0.6$, as a result, their opinions are not considered to be compatible. While calculating the value of $\chi^{2}$ when the selected significance value is $\alpha=0.05$ and the degree of freedom is $v=7$, it was found that the opinions of expert were compatible, because $\chi^{2}>\chi_{k r}^{2}$.

Taking into account the compatible opinions of the Lithuanian and Danish experts and the results that were calculated by following two different methods, it might be concluded that the results are reliable. Recommendations about the improvement of the composition of the NSD model and its testing in the conditions of the selected business enterprise can be provided.

The questionnaire that was given to the Lithuanian and Danish experts included 4 open questions related to the structure of the model. All experts were asked about the demand to perform a simulation of a new conceptual service with company employees or potential consumers. The results of the survey revealed that simulation is a very important component of NSD. The experts revealed that simulation with employees can reduce the possibility of mistakes. Testing the concept of service with consumers might reduce the potential misinterpretation of their needs. Also, this method allows companies to identify the result that has been set. The second question highlighted the short-term post-launch assessment of a new service as it helps to identify the critical faults and values of a newly developed service. It also gives a possibility to identify the potential delivering channels and form a more effective marketing strategy. The third question asked to evaluate the impact of competitors during the stage of formation and it was noticed that despite the stated importance of this activity, the majority of experts had not excluded any specific significance or correlation with other activities. According to experts, the competitive analysis is needed to be done in all scales to be able to evaluate the potential risks or public data during the stage of formation. Finally, the experts were asked, if the given score to the item of this questionnaire was a higher one (e.g., 7 (not important) or 8 (not important at all)) does it mean that such activity of the NSD model can be considered as inappropriate and it was found out that such activities of the model are important, but because of the given choice of scores arrangements in the overall context of other activities they might seem less important.

Based on the results of the survey, four improvements for the model of NSD have been proposed:

It is proposed to reformulate the activity of the relevance of the idea to specific groups of consumers during the stage of preparation. Based on the survey results, the majority of experts rated this activity as important but less significant than other activities of this stage. Therefore, it is suggested to add the phrase "if necessary" to the current formulation.

Taking the activity of location and environment of the staff training and preparation into account, it is proposed to change the current formulation into "training for employees involved in the provision of the service" during the stage of formation. This adjustment is based on the fact that the principles of providing a new service are usually explained to the specific type of employees.

Two adjustments are proposed for the environment of competitors: 1) During the stage of analysis, it is proposed to change the activity of "threat assessment of new competitors" 


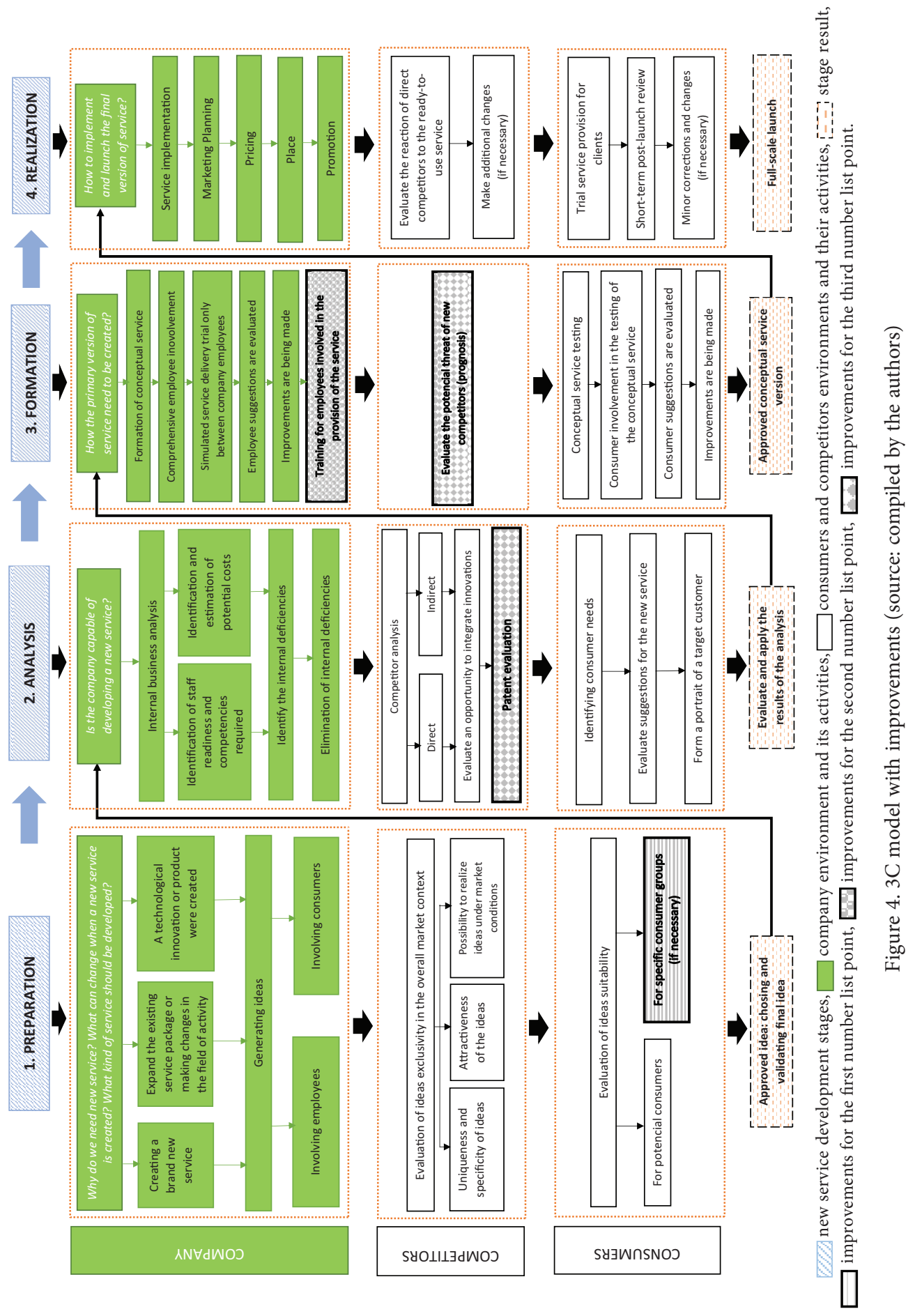


into the activity "patent evaluation" in order to ensure the protection and respect rights of technology or intellectual property and to assess any restrictions; 2) During the stage of formation, it is proposed that the activity of "additional external environment analysis" would be replaced by the activity of "threat assessment of new competitors" in order to determine whether new competitors have appeared on the market before moving to the stage of service realization (see Figure 4).

The results of the survey made it possible to change the formulations of the activities of the proposed model for NSD, but also to propose the inclusion of a completely new activity (patent evaluation) to the overall composition of the proposed model. These adjustments allowed to improve the service development process by detailing it more precisely in each of the environments. Also, research results showed that the comparative analysis of previous models presented in the scientific literature may not be sufficient for the formation of a NSD model, as experts may provide recommendations for the model composition that would become particularly relevant during its testing. In this case, the suggestions facilitated the preparation of further studies related to the model.

Another important aspect is the evaluation of actions that fall into both the different environments of the model and the stages. It allowed to supplement the theory of innovation by distinguishing the actions of the NSD stages and assigning them to specific elements of the organizational environment, which enables the application of targeted solutions, in order to manage the process of NSD effectively.

\section{Recommendations for the application of the model for NSD in business companies}

The companies whose experts have filled in the questionnaires are currently developing or have developed a new service during a period that is not longer than one year. Most of the companies that participated in the survey are constantly developing new solutions that later are transformed into new services used by many different consumers (e.g. e-commerce solutions that give consumers the possibility to purchase goods or services online; self-scanning; self-service shops, etc.). Considering the fact that many modern companies develop new services, improve their processes and expand the range of their services according to the needs of consumers, changes happening in the competitive environment or new market-dominant technological innovations, it is recommended to apply the model for NSD and the algorithm of its implementation to those companies that fit into the following groups:

Is considering to create a brand new service that has no equivalent in the world or certain territories (city, country, and region). For example, a service that has some counterparts in other countries is planned to be developed/is already deployed in a country where it has not been launched yet (such as sharing services, mail machines, etc.).

Is developing some technological solutions regularly (such as artificial intelligence, cybersecurity, cloud enablement, etc.), that are later adapted to the service delivery process and a developed company also becomes an administrator of a new service (see Figure 5).

Has created a product (such as an e-scooter) and now is considering to use this product for the purposes of sales and service providing (see Figure 5). 
Is planning to change the line of business or expand the range of services (e.g., a company that is providing physical training wants to start providing e-learning to its consumers in order to reach a larger audience).

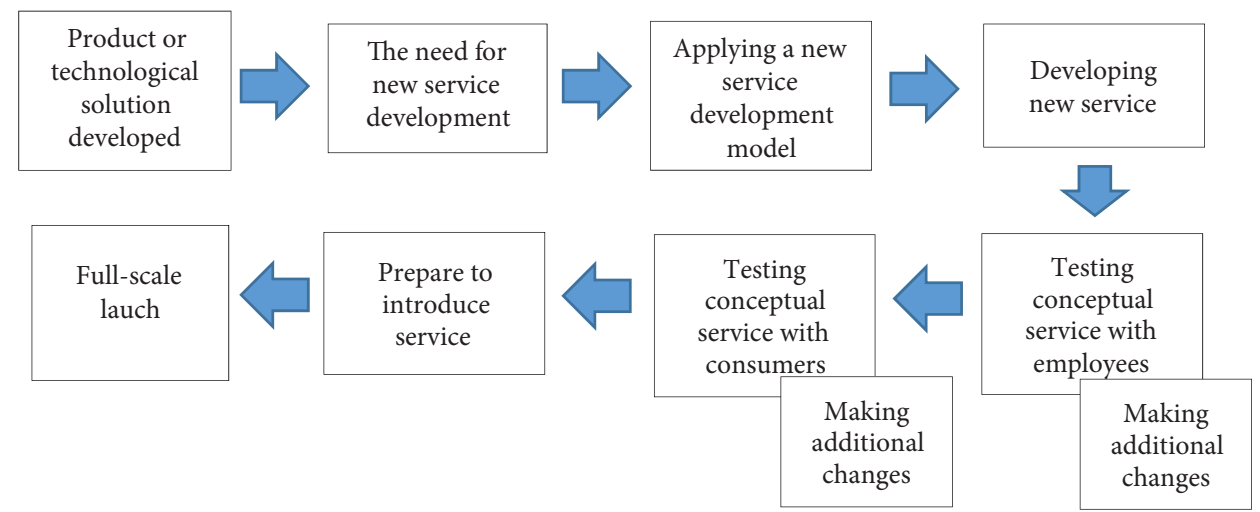

Figure 5. Possibilities of applying a NSD model after product or technological solution creation (source: compiled by the authors)

These groups allow business subjects to identify the applying direction of a model for NSD (brand new service; product developed to be used for service delivery; changing business line; expanding range of services; developing technology solutions) and assigning the company to one of the above-mentioned directions. It also helps to get initial information about the specifics of the model application when the algorithm of implementation might be changed according to the groups chosen by a business entity (e.g., if there is a developed product that is going to be used for a newly developed service, the preparation stage might be eliminated, as a result, the business entity can start with the stage of analysis. However, if a new service is developed from scratch, the entire process might be executed sequentially) or its periodicity (e.g., if a company is developing technological solutions regularly and is going to adapt them to a process of service delivery).

\section{Conclusions}

The proposed model for NSD consists of 4 stages (preparation, analysis, formation, and realization) and 3 environments (company, competitors and consumers). Every each of these environments can be analysed during all stages and every stage can be analysed in every each environment. The activities of this model can be analysed in the internal context of the company, as well as, in the contexts of competitors and consumers due to the distinguished environments. As a result, the impact of external factors on the process can be highlighted. The activity of monitoring, integrated into the stage of realization, includes a short-term post-launch review of a newly developed service, as a result, a business subject is able to determine what actions are needed to be taken before the full-scale launch. This structure of the model allows the service-providing company to manage the entire development process of the service properly and take the internal and external factors into account. 
The survey of experts has revealed that the activities attributed to the environment of competitors were rated as less important than the activities attributed to the environments of the company or consumers. It can be assumed that the development of a new service is based on the user experience, therefore the environment of competitors is considered as less important than the environments of company or consumers. The experts had similar and consumer-oriented opinions when it comes to employee engagement in the process of generating new ideas. This activity is considered as less important. Such results can be based on the fact that most new ideas are dictated by the market and consumer needs.

According to the results of the survey, the adjustments of elements of the model for NSD were proposed about the reformulation and formation of a new element (patent evaluation). These adjustments help to improve the process of service development by making it more detailed in every environment and taking the results of the expert survey into account. The model is prepared for further researches.

The advisory groups have been proposed for the model application in the context of service-providing companies (brand new service; product developed to be used for service delivery; changing business line; expanding range of services; developing technology solutions). These groups allow business entities to identify the direction of the model development and assigning the company to one of the above-mentioned directions according to the current needs. It also helps to get initial information about the specifics of the model application when the algorithm of implementation might be changed according to the groups chosen by a business entity.

This study is limited to data collected from experts in one sector. An opportunity, therefore, exists to evaluate the composition of the proposed model of NSD in other countries and sectors. In order to verify the established model for NSD, it is planned to carry out further researches that might be divided into 3 main stages: 1) to obtain more information about the duration (optimistic, most-likely, pessimistic) of the activities at each stage of the development of new services, a second questionnaire was sent to the selected experts and they were asked to make a three-point estimation, 2) after applying the PERT (Program Evaluation and Review Technique) and Monte Carlo simulation methods, the suggestions for efficient time management will be formed for every stage of NSD, 3) the model for NSD will be empirically tested in the company that is providing and developing new services.

\section{Disclosure statement}

The authors declare no conflict of interest.

\section{References}

Akhmetshin, A. M., Plaskova, N. S., Iusupova, I. I., Prodanova, N. A., Leontyev, A. N., \& Vasilev, V. L. (2019). Dataset for determining rational taxation value with incompatible criteria of economic efficiency and equity. Data in Brief, 26, 1-11. https://doi.org/10.1016/j.dib.2019.104532

Alam, I., \& Perry, C. (2002). A customer-oriented new service development process. Journal of Services Marketing, 16(6), 515-535. https://doi.org/10.1108/08876040210443391 
Bauer, T., \& Borodako, K. (2019). Trade show innovations - Organizers implementations of the new service development process. Journal of Hospitality and Tourism Management, 41, 197-207. https://doi.org/10.1016/j.jhtm.2019.10.005

Burger, T., Kim, K. J., \& Meiren, T. (2010). A structured test approach for service concepts. International Journal of Service Science, Management, Engineering, and Technology, 1(4), 12-21. https://doi.org/10.4018/jssmet.2010100102

Cioacă, S., Cristache, S., Vută, M., Marin, E., \& Vută, M. (2020). Assessing the impact of ICT sector on sustainable development in the European Union: An empirical analysis using panel data. Sustainability, 12(2), 1-16. https://doi.org/10.3390/su12020592

Corrocher, N., \& Ozman, M. (2019). Green technological diversification of European ICT firms: A patent based analysis. Economics of Innovation and New Technology, 29(6), 559-581. https://doi.org/10.1080/10438599.2019.1645989

Drejeris, R. (2015). Nauju paslaugu kūrimo ir diegimo kiekybiniai sprendimai: nuo idejų generavimo iki sèkmés vertinimo. Akademija. https://www.vdu.lt/cris/handle/20.500.12259/88642

Drejeris, R., \& Vestertè, J. (2015). New public service development: Identifying elements of process model. Journal of System and Management Sciences, 5(3), 65-83. http://www.aasmr.org/jsms/Vol5/No.3/JSMS-VOL5-NO3-5.pdf

Edvardsson, B., Meiren, T., Schaefer, A., \& Witell, L. (2013). Having a strategy for new service development - does it really matter? Journal of Service Management, 24(1), 25-44. https://doi.org/10.1108/09564231311304170

Eurostat. (2017). ICT sector - value-added, employment and R\&D. https://ec.europa.eu/eurostat/statistics-explained/index.php/ICT_sector_-_value_added,_employment_and_R\%26D

Eurostat. (2019). High-tech statistics - employment. Average annual growth rate of employment in KIA in 2008-2017. https://ec.europa.eu/eurostat/statistics-explained/pdfscache/46747.pdf

Froehle, C. M., \& Roth, A. V. (2007). A resource-process framework of new service development. Production and Operation Management, 16(2), 169-188. https://doi.org/10.1111/j.1937-5956.2007.tb00174.x

Gaus, O., Neutschel, B., Raith, M. G., \& Vajna, S. (2013). How designed communication supports new product \& service development. iBusiness, 5(3B), 10-17. https://doi.org/10.4236/ib.2013.53B003

Geissdoerfer, M., Vladimirova, D., Fossen, K., \& Evans, S. (2018). Product, service, and business model innovation: A discussion. In Global Conference on Sustainable Manufacturing (pp. 165-172). Elsevier B.V. publishing. https://doi.org/10.1016/j.promfg.2018.02.107

Hsu, P. H. (2017). Constructing a innovative service development process base on ethics. International Journal of Social Science and Humanity, 7(2), 76-81. https://doi.org/10.18178/ijssh.2017.V7.799

Yousuf, M. I. (2007). Using experts opinion through Delphi technique. Practical Assessment, Research \& Evaluation, 12(4), 1-8. https://doi.org/10.7275/rrph-t210

Yu, E., \& Sangiorgi, D. (2018). Service design as an approach to implement the value co-creation perspective in new service development. Journal of Service Research, 21(1), 40-58. https://doi.org/10.1177/1094670517709356

Yu, E., \& Sangiorgi, D. (2014). Service design as an approach to new service development: Reflections and future studies. In ServDes.2014. Fourth Service Design and Innovation Conference "Service Futures" (pp. 194-204). Lancaster, United Kingdom. http://www.servdes.org/wp/wp-content/uploads/2014/06/Yu-E-Sangiorgi-D.pdf

Jin, D., Chai, K., \& Tan, K. (2014). New service development maturity model. Managing Service Quality: An International Journal, 24(1), 86-116. https://doi.org/10.1108/MSQ-10-2012-0134

Kendall, M. G. (1970). Rank correlation methods (4 ${ }^{\text {th }}$ ed.). Griffin. 
Kitsios, F., \& Kamariotou, M. (2019). Mapping new service development: A review and synthesis of literature. The Service Industries Journal, 40(9-10), 682-704.

https://doi.org/10.1080/02642069.2018.1561876

Libby, R., \& Blashfield, R. K. (1978). Performance of a composite as a function of the number of judges. Organizational Behavior \& Human Performance, 21(2), 121-129.

https://doi.org/10.1016/0030-5073(78)90044-2

Lietuvos bankas. (2020). Paslaugu eksportas ir importas pagal paslaugos rūšs̨i ir šalį. https://www.lb.lt/lt/paslaugu-eksportas-ir-importas-pagal-paslaugos-rusi-ir-sali

Lin, F., \& Hsieh, P. (2011). A SAT view on new services development. Service Science, 3(2), 141-157. https://doi.org/10.1287/serv.3.2.141

Lund, S., Manyika, J., Woetzel, J., Bughin, J., Krishnan, M., Seong, J., \& Muir, M. (2019). Globalization in transition: The future of trade and value chains. Mckinsey Global Institute. https://www.mckinsey. $\mathrm{com} /$ featured-insights/innovation-and-growth/globalization-in-transition-the-future-of-trade-andvalue-chains

Mas, M., Fernández de Guevara, J., Robledo, J. C., Righi, R., Cardona, M., \& Samoili, S. (2019). The 2019 PREDICT Key Facts Report. An Analysis of ICT R\&D in the EU and Beyond (JRC Technical Reports). European Commission. https://doi.org/10.2760/06479

Motienė, R., Gudelis, A., Dibisteris, A., \& Steniukynas, M. (2017). Inžinerinés ir edukacinès technologijos: moksliniu straipsniu rinkinys. Kauno technikos kolegija. http://www.ktk.lt/assets/Uploads/zurnalas-2017-new.pdf

Podvezko, V. (2008). Sudetingų dydžiu kompleksinis vertinimas. Business: Theory \& Practice, 9(3), 160-168. https://doi.org/10.3846/1648-0627.2008.9.160-168

Pridotkienè, J., \& Pridotkas, R. (2012). Reikšmingų nefinansinių rodiklių nustatymas vertinant eksporto prekinio kredito riziką. Economics and Management, 17(3), 1016-1020.

https://doi.org/10.5755/j01.em.17.3.2112

Rapaccini, M., Saccani, N., Pezzotta, G., Burger, T., \& Ganz, W. (2013). Service development in productservice systems: A maturity model. The Service Industries Journal, 33(3-4), 300-319. https://doi.org/10.1080/02642069.2013.747513

Reinoso, M., Lersviriyajitt, S., Khan, N., Choonthian, W., \& Laosiripornwattana, P. (2009). New service development: Linking resources, processes, and the customer. In PICMET 2009 Proceedings (pp. 2921-2932). IEEE Publishing. https://doi.org/10.1109/PICMET.2009.5261784

Riedl, C., Leimeister, J. M., \& Krcmar, H. (2011). Why e-service development is different: A literature review. e-Service Journal, 8(1), 2-22. https://doi.org/10.2979/eservicej.8.1.2

Santana, F. E., Cardoso, C. C., Ferreira, M. G. G., Catapan, M. F., Montanha, I. R., \& Forcellini, A. F. (2018). Towards a more inclusive service development process for the wider population. Design Studies, 55, 146-173. https://doi.org/10.1016/j.destud.2017.10.003

Santos, J. B., \& Spring, M. (2013). New service development: Managing the dynamic between services and operations resources. International Journal of Operations and Production Management, 33(7), 800-827. https://doi.org/10.1108/IJOPM-12-2012-0559

Scheuing, E. E, \& Johnson, E. M. (1989). A proposed model for new service development. Journal of Services Marketing, 3(2), 25-34. https://doi.org/10.1108/EUM0000000002484

Shekar, A. (2007). An innovative model of service development: A process guide for service managers. The Innovation Journal: The Public Sector Innovation Journal, 12(1), 1-18.

Skačkauskienė, I., Švogžlys, P., \& Lemańska-Majdzik, A. (2019). Formation of a conceptual model for new services. Polish Journal of Management Studies, 19(2), 374-384.

https://doi.org/10.17512/pjms.2019.19.2.32 
Stevens, E., \& Dimitriadis, S. (2005). Managing the new service development process: Towards a systemic model. European Journal of Marketing, 39(1/2), 175-198. https://doi.org/10.1108/03090560510572070

Šateikienè, D., Janutienė, J., Bogdevičius, M., \& Mickevičienė, R. (2015). Analysis into the selection of ballast water treatment system. Transport, 30(2), 145-151. https://doi.org/10.3846/16484142.2015.1045025

Švogžlys, P. (2020). The structure of model for new services development. Journal of System and Management Sciences, 10(2), 21-39. http://www.aasmr.org/jsms/Vol10/Vol.10.2.2.pdf

Torney, M., Kuntzky, K., \& Herrmann, C. (2009). Service development and implementation - A review of the state of the art. In Proceedings of the $1^{\text {st }}$ CIRP Industrial Product-Service Systems (IPS2) Conference. Cranfield University.

Zeithaml, V. A., Bitner, J. M., \& Gremler, D. D. (2017). Services marketing: Integrating customer focus across the firm ( $7^{\text {th }}$ ed.). McGraw-Hill. 